УAK 551.762.3:56.074.6:551.8(477.8)

\title{
N.M. Zhabina \\ SEDIMENTARY MODEL OF THE UPPER JURASSIC - LOWER CRETACEOUS CARBONATE COMPLEX IN THE UKRAINIAN PRECARPATHIANS
}

\author{
Жабіна Н.М. \\ СЕАИМЕНТАЦІЙНА МОАЕАЬ КАРБОНАТНОГО КОМПАЕКСУ ВЕРХНЬОї ЮРИ - НИЖНЬОї КРЕЙАИ В \\ УКРАÏHСЬКОМУ ПЕРЕАКАРПАТTI
}

\begin{abstract}
In the Ukrainian Precarpathians the Oxfordian - Valanginian deposits compose a common carbonate complex. Seven types of sections are determined in its composition: fore-reef, reef, back-reef, transitional, lagoon, shallow-water, outlying. The conditions of their sedimentation are characterized. The main stages of these deposits sedimentation related with eustatic fluctuations are determined: Oxfordian, Oxfordian - Kimmeridgian boundary, Early Kimmeridgian, Late Kimmeridgian - Early Tithonian, Late Tithonian - Early Berriassian, Early and Late Berriassian boundary, Late Berriassian - Valanginian. The sedimentary model of these deposits has been carried out. Keywords: sedimentary model, types of sections, facies, Upper Jurassic, Lower Cretaceous, Ukrainian Precarpathians.
\end{abstract}

\begin{abstract}
В Українському Передкарпатті віАклади оксфорду - валанжину складають єАиний карбонатний комплекс. В його складі виАімено сім типів розрізу: передрифовий, рифовий, зарифовий, перехідний, лагунний, периферійний. Охарактеризовані умови їх формування. Визначено головні стадії седиментації цих відкладів, що пов'язані з евстатичними змінами: оксфорА, межа оксфорАу і кімериАжу, ранній кімериАж, пізній кімериАж - ранній титон, пізній титон - ранній беріас, межа раннього і пізнього беріасу, пізній беріас - валанжин. Створена седиментаційна модель цих відкладів.

Ключові слова: седиментаційна модель, типи розрізів, фації, верхня юра, нижня крейда, Українське Передкарпаття.
\end{abstract}

\section{INTRODUCTION}

In the Ukrainian Precarpathians the Oxfordian - Valanginian carbonate complex of the genetically related rocks extends as submeridional stripe to above $100 \mathrm{~km}$ width along the Stryi depression area. This complex is represented by the deposits of carbonate shelf from more deep-water in the west till the shallow-water in the east. There are the Oxfordian - Lower Berriassian reefogenic facies and Upper Berriassian - Valanginian open shelf deposits. In accordance with the stratigraphic scheme (Zhabina, Anikeyeva, 2007), these facies are represented by suites: fore-reef ones - Boniv (Oxfordian), Moranci (Kimmeridgian), Karolina (Tithonian - Lower Valanginian); reef facies - Rudki suite (Oxfordian) and Opary (Kimmeridgian lower subsuite and Tithonian - Lower Berriasian upper subsuite), back-reef facies - Gorodok suite (Oxfordian), Pidluby (Lower Kimmeridgian), Nyzhniv (Upper Kimmeridgian Lower Tithonian), Bukivna (Upper Tithonian - Lower Berriasian), evaporite lagoon facies - Rava-Russka suite (Lower Kimmeridgian), shallow-sea deposits Stavchany suite (Upper Berriassian - Valanginian). This complex is considerably eroded, it lies on the Paleozoic fundament and in the north - west of depression on the Middle Jurassic deposits, overlapped by the Aptian-Albian, Upper Cretaceous or Miocene deposits.

The sedimentation of these deposits took place in northern periphery of Tethys by the influence of the
World ocean eustatic fluctuations. Changes of the sedimentation conditions in accordance with the eustatic fluctuations caused forming the different types of sections and complicated structure of the whole complex in the vertical and lateral directions. This sedimentary model is shown in the picture (fig. 1).

\section{MATERIALS AND METHODS}

In the Ukrainian Precarpathians the Upper Jurassic Lower Cretaceous carbonate complex outcrops in the river Dnister basin and was opened by wells in the Carpathian Foredeep and adjacent part of the East-European platform. We have conducted a complex study of materials of 240 wells and natural sections of these deposits having used lithology-sedimentological, bioand sequens-stratigraphical analysis and having taken into an account the results of petrographic, paleontological and geophysical studies fulfilled by other experts (Dulub at al., 1986, 2003, and other).

\section{DISCUSSION AND RESULTS}

The Upper Jurassic - Lower Cretaceous deposits in the region studied were formed in the North Tethys paleobasin. The main factor of this carbonate complex forming was reef-building processes taken place during Late Jurassic and Early Berriasian. There are determined seven types of sections formed in the different zones of the paleobasin (fig. 2). They are characterized by the specific lithological and paleontological composition as a result of different sedimentation 


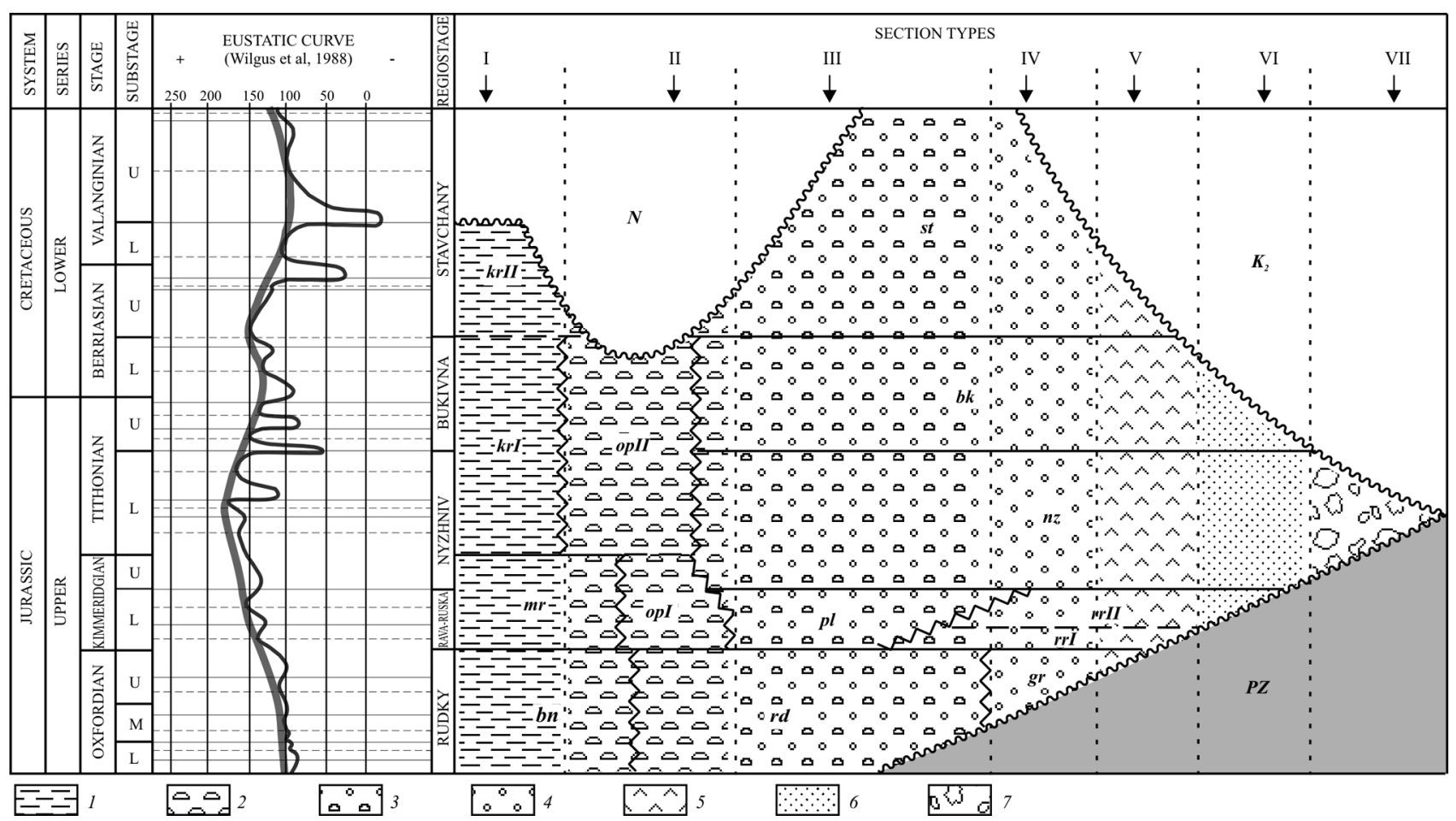

Fig 1. Sedimentary model of the Upper Jurassic - Lower Cretaceous carbonate complex in the Ukrainian Precarpathians.

1 - 3 - Carpathian overthrusts; 4 - regional faults (Kr - Krakowets, Gr - Gorodok, SV - Sudova Vyshnya, KI - Kalush, Nd - Nadvirna, Ks - Kosiv); 5 - drilling areas; 6 - wells, 7 - eastern boundary of Upper Jurassic sediments; 8 - 14 - types of section: 8 - fore-reef, 9 - reef, 10 - back-reef, 11 -transitional, 12 - lagoon, 13 - shallow-water, 14 - outlying. The Krakowets Fault is the western boundary of Upper Jurassic sediments.

conditions and their changes in time. Fore-reef, reef and transitional types of section were opened by drilling only in the north - west of the Carpathian Foredeep. In the south-east they are overlapped by the Carpathians overtrusts.

I type of section (fore-reef) was opened by drilling in Karolina, Niklovichi, Volosha, Oselia, Grushiv, Orchovichi, Rosiv, Morantci and other areas. These deposits were formed in fore-reef zone in the west of the reef belt. This section is composed of the suites: Boniv (to $280 \mathrm{~m}$ thick), Morantci (to $300 \mathrm{~m}$ ), Karolina (to $500 \mathrm{~m}$ ). It is represented by the limestones (micritic, oncoidal, bioclastic, and brecciated) interbedded with mudstones, siltstones, gravellites and breccias. These rocks often contain materials of the destruction of reef. Layers of the silicified limestones were formed in transgressive stages, the sandstones and shallow-water limestones reflect the regressive events. This section lies on the Middle Jurassic Javorov suite and overlaped by the Miocene deposits. Thickness of forereef section is to $1130 \mathrm{~m}$, decreasing in some lots.

Sedimentation of these deposits took place in pelagic environments. Numerous vestiges of planc- tonic biota witness about that. Appearance of the planctonic foraminifers and tintinnids in Early Oxfordian were related to rising sea-level. At the Oxfordian - Kimmeridgian boundary, at the end of Early Tithonian and Late Tithonian, during Early Valanginian tintinnids associations were poor in abundance and diversity because of the regressive events. New genera of tintinnids appeared at Late Kimmeridgian, Late Tithonian, during Berriassian correlating with the sea-level rise. Numerous vestiges of siliceous sponges in the Lower Oxfordian microfacies and bentic foraminifers dominating in associations with plantonic microfauna in higher beds were related to sedimentation in the upper zone of open shelf on 50-100 m depth (maximum in Early Oxfordian). Extention of the fore-reef section to the east for $12 \mathrm{~km}$ in Oxfordian and for $5 \mathrm{~km}$ during Kimmeridgian and Tithonian was a result of the largest amplitude of sea-rise at Late Jurassic beginning and result of the global regressive background after that (Zhabina, Anikeyeva, 2003).

II type of section (reef) was opened by drilling in Kochanivka, North Medenichi, Grushiv, Podiltci and other areas. In the central part the section is 


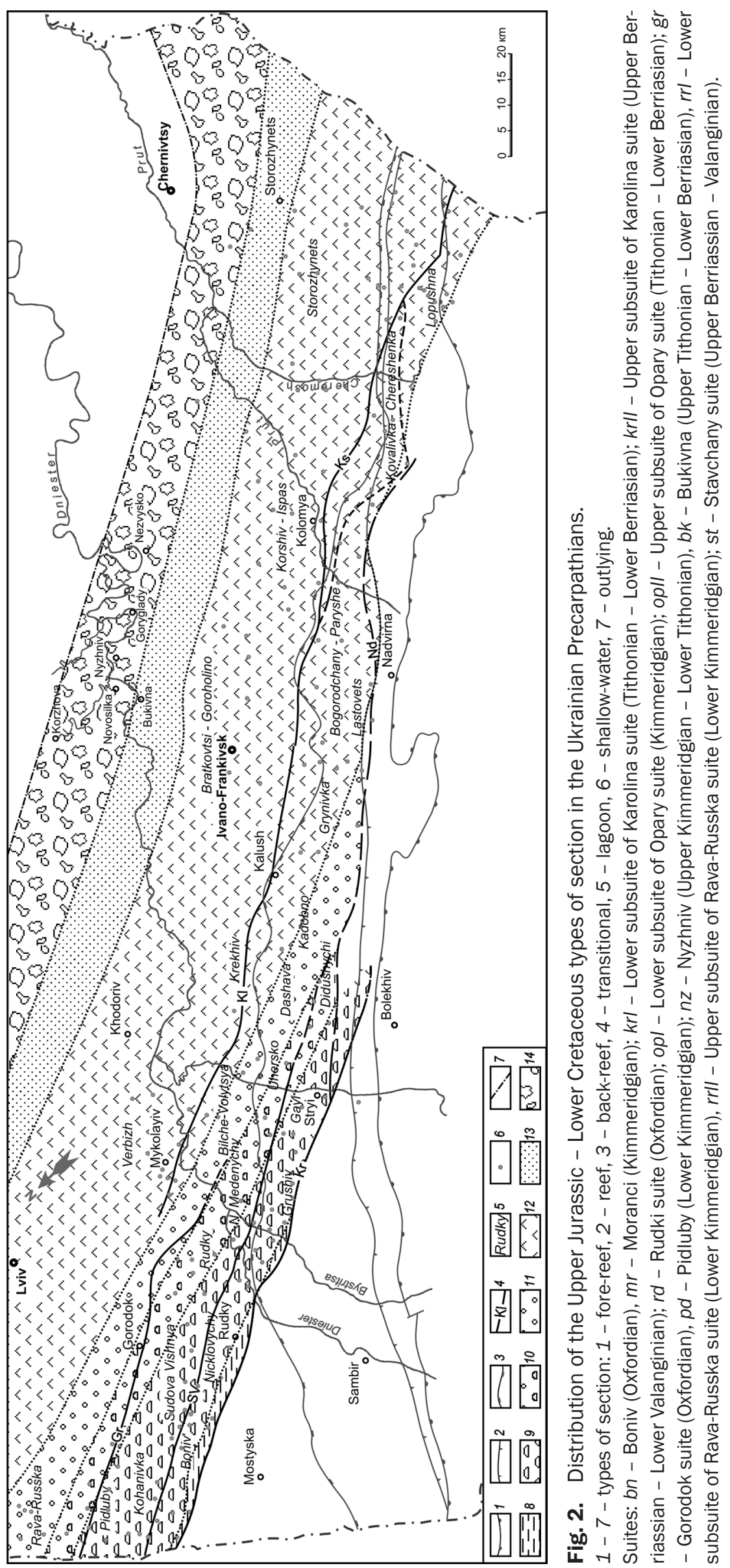


composed of the Oxfordian bioherms (Rudki suite) and Kimmeridgian - Early Berriasian barrier reef (Opary suite). Oxfordian and Kimmeridgian reef deposits are replaced by the fore-reef Boniv and Morantci suites in the western part of this type of section (South Kochanivka, Bortiatin and other areas) and by back-reef Gorodok and Pidluby suites in the east (Gayi and Stryi areas). Opary barrier reef was formed on the more deep-water basis in the west and on the more shallow-water basis in the east (Anikeyeva, 2005). In the top of this section reef deposits locally are overlapped by shallow-sea Stavchany suite. Oxfordian biogermes were separate buildups (to $150 \mathrm{~m}$ thick), which built by sponges at the bottom and by corals and algae above. At the top they are overlapped by the oncolitic limestones. Deposits between biohermes are composed of bioclastic, biomicritic, sandy and brecciated limestones interbedded with siltstones and breccias. Kimmeridgian reef deposits (to $450 \mathrm{~m}$ thick) are composed of the biomicritic and bioclastic limestones (algal-sponge, foraminifera-algal with corals and bryozoans) with interlayers of silicified limestones and gravellites. At different levels of the Kimmeridgian section there are separate algal-sponge bioherms (10-70 m thick). Tithonian - Early Berriasian reef deposits (to $800 \mathrm{~m}$ thick) are composed of bioclastic and biogermic limestones (created by corals, sponges, algae, bryozoans, stromatopores). Reef section lies on the Middle Jurassic Javorov suite and is overlapped by the Miocene deposits. Thickness of this section is about $1370 \mathrm{~m}$.

Reef belt was formed parallelly to the coastline in the lower sublittoral. In accordance with the reef builders paleoecology (Anikeyeva, 2002) reefbuilding processes took place in Oxfordian at first on the $100 \mathrm{~m}$ deep (siliceous sponge witness about that), after that the deeps of the sedimentation were decreased (calcareous sponge, algae, corals at Late Oxfordian). At the end of Oxfordian building biogermes was stopped what was related to large regression (oncolitic limestones lie in the top of biohermes). Reef buildups were formed on the sloping shelf to 20-40 m deep during Kimmeridgian (calcareous sponges, algae, corals) and on the sublitoral to 25- $30 \mathrm{~m}$ during Tithonian - Early Berriasian (corals, sponges, bryozoans, stromatopores). During Kimmeridgian - Early Berriasian reef section was considerably moved to the west because of the influence of the global regression

III type of section (transitional) extends in the east of the Opare reef, it was opened by drilling in
Pidluby, Nemyriv, Rudky, North Medenichi and other areas. This section is determined at the place of substitute of the Oxfordian reef and back-reef facies and the Lower Kimmeridgian back-reef and lagoon facies. These deposits are overlapped by the back-reef Nizhniv and Bukivna suites with the Stavchany suite in the top. Two last of these suits were eroded in some places. Oxfordian deposits (to $100 \mathrm{~m}$ thick) are composed of bioclastic and oncolitic limestones with interlayers of biogermic (sponge) and silicified limestones. Lower Kimmeridgian deposits (to $200 \mathrm{~m}$ thick) are represented at the bottom by lower subsuite of Rava-Russka suite. There are mottled calcareous-terrigenous rocks with anhydrites and gypsum. These deposits are overlapped by Pidluby suite - shallow-water limestones (bioclastic, biomicritic, oncoidal) and dolomites with the strata and fragments of sponge limestones. Nizhniv suite (60-150 m thick) is represented at the bottom by the horizon of breccias with fragments of limestones and siltstones. It is overlapped by oncolitic and dolomitic limestones interbedded with dolomites. Bukivna suite is composed of bioclastic limestones with macrofauna and algae vestiges at the bottom (20-70 m), oncolitic limestones lie above of that, at the top with the beds of sandy limestones $(13 \mathrm{~m})$. Stavchany suite is composed of three packs: lower (Upper Berriasian) - mudstones, siltstones and bioclastic limestones (to $17 \mathrm{~m}$ thick); middle (Lower Valanginian) - bioclastic and oncoidal limestones interbedded with clays (to $60 \mathrm{~m}$ thick), upper (Upper Valanginian) - sandy limestones and marls with glauconite (to $70 \mathrm{~m}$ thick). The transitional section lies on the Paleozoic deposits, on the Middle Jurassic Javorov suite in the north-west and is overlaped by the Upper Cretaceous rocks, in places by Aptian - Albian. Thickness of this section is up to $600 \mathrm{~m}$.

These deposits are characterized by vertical replacing the Oxfordian relatively deep-water formations by the Lower Kimmeridgian shallow-water ones. Oxfordian deposits were formed on depth of $100 \mathrm{~m}$ (the beds with sponge and silicified limestones show that). Lower Kimmeridgian lagoon and back-reef deposits were formed on depth to first tens meters (contain numerous vestiges of reef-loving bentic fauna and fragments of reefbuilders). During Late Berriasian and Valanginian the sedimentation took place on the open sublittoral to $50 \mathrm{~m}$ deep (Stavchany suite contain numerous shallow-water fauna, but reef-loving species is not multiplicity). 
IV type of section (back-reef) extends to the east of Opary reef all over the periphery the disposition of the carbonate complex. Oxfordian deposits were opened by wells only in the north of Carpathian Foredeep. Back-reef formations are represented by shallow-water limestones (oncoidal, bioclastic, biogermic, biomicritic, micritic) and dolomites with the beds of mudstones and sandstones, near the coast by bioclastic limestones, carbonate clays, lito-bioclastic sandstones and conglomerates. Lagoon was isolated in the back-reef zone of basin at Oxfordian - Kimmeridgian boundary as a result of global regression. The lagoon existed during Early Kimmeridgian. Evaporite lagoon sediments are dolomites, anhydrites, gypsum, mudstones, siltstones, sandstones and breccias. Back-reef section is composed of the Oxfordian - Lower Berriasian back-reef facies and Lower Kimmeridgian lagoon facies. Gorodok suite (30-40 m thick) composed of sandy and silty limestones with interlayers of mudstones in the bottom. Above lie Rava-Russka suite (up to $300 \mathrm{~m}$ thick), Nyzhniv suite (about $200 \mathrm{~m}$ thick) and Bukivna suite (up to $60 \mathrm{~m}$ thick). In the Didushychi and South Grynivka areas at the top of the section lie Upper Berriasian beds of Stavchany suite (up to $40 \mathrm{~m}$ thick) represented by bioclastic sandy and brecciated limestones with macrofauna fragments. Back-reef section lies on the Paleozoic or Middle Jurassic deposits and is overlapped by Upper Cretaceous, in places by Aptian-Albian. Thickness of this section is up to $640 \mathrm{~m}$.

Sedimentation of these deposits took place on the back-reef plain with small deeps (to 25-40 m). Numerous vestiges of the reef-loving organisms and the inhabitants of the shallow water and stagnant sea (mollusks, brachiopods, ostracods, bryozoans, sponges, corals, sea-urchins, fish, algae, crayfishes) and wide development of the warmly water large bentic foraminifers testify about that. Occurrence of tintinnids marks the transgressive events.

The section with Oxfordian deposits formed on upper sublittoral of basin was opened in the north east by the wells Rava-Russka-2 and Velyki Mosty-2. These deposits are represented by limestones with interlayers of calcareous siltstones and sandstones. Single shells of sea foraminifers were found only in one bed of calcareous siltstones. These rocks contain Paleozoic coal and quarzite pebbles - products of destruction of Paleozoic coast. They are overlapped by littoral siltstones and sandstones with vegetable vestiges. They lie at the angle of $10-15^{\circ}$ and are similar to Middle Jurassic Sokal suite situated in this area. That can be related with falling rocks of Sokal suite off the coast of Oxfordian sea. Rava-Russka suite lies above and is overlapped by Nizhniv suite. Nizhniv suite is eroded in Rava-Russka area and is absent in Velyki Mosty area.

V type of section (Iagoon) extends as submeridional stripe to $40 \mathrm{~km}$ width along a whole shallowwater zone of the Late Jurassic paleobasin and was opened by drilling in Storozhinets, Solonets, Krasnoilsk, Gilche, Segii, Migovo, Petrovets, Lopushna, Kamjanka, Kovalivka-Chereshenka, BogorodchanyParyshe, Bogorodchany, Korshiv-lspas, Verbish, Krekhiv, Rava-Russka, Lubelia, Kadobno, South Kadobno, Verchany, Dashava, Stavchany, Didushichi, Trostianets, Peremyshliany, Rogatin, VynnykyBibrka, Mala Gorozhanka, Seredniy Majdan and other areas. This section formed in the territory of Early Kimmeridgian lagoon is composed by Lower Kimmeridgian lagoon facies (Rava-Russka suite) and Upper Kimmeridgian - Early Berriasian backreef facies (Nyzhniv and Bukivna suites) somewhere with Stavchany suite at the top. Rava-Russka suite (20-350 m thick) is represented by mottled (prevailly red) mudstones, siltstones, sandstones, gravellites, konglomerates and breccias with anhydrite-dolomite cement with inclusions and beds of anhydrites, gypsum and dolomites in the lower part. In the upper part this suite is represented by the succession of gray dolomites and dolomitic limestones, anhydrites, mudstones. Nyzhniv suite (6$200 \mathrm{~m}$ thick) is composed of limestones (dolomitic, biomicritic, bioclastic) and dolomites, in places with clay beds, sandy and gravellitic admixture. Bukivna suite (2-60 $\mathrm{m}$ thick) is composed of biomicritic and bioclastic limestones, in the upper part iterbedded by oolitic limestones. Stavchany suite $(20-50 \mathrm{~m})$ is composed of mudstones with interlayers of sandstones and sandy limestones in the lower part and is represented by bioclastic limestones sometimes with glauconite in the upper part. Lagoon section is often greatly eroded (sometimes to Rava-Russka suite). It lies on Paleozoic deposits, in places (Lubelia, Verbizh at other areas) on the Middle Jurassic Sokal suite and is overlapped by Upper Cretaceous or Miocene formations. Thickness of the section is variable, up to $310 \mathrm{~m}$, decreases to the east.

Early Kimmeridgian lagoon was very salted shallow-water basin. Lagoon rocks contain only favreins, cianofitus, mollusks, gastropods, ostracods, siliceous foraminifers. In middle of Kimmeridgian lagoon disappeared because of the global transgression. After that back-reef facies were formed in that area. 
VI type of section (shallow-water) outcrops along the right bank of river Dnister, consists only of Nyzhniv and Bukivna suites. Nyzhniv suite is composed of oncolitic and bioclastic limestones. Bukivna suite is represented by the mollusc-algal bioherms. This section is overlapped by Cenomanian sandstones. Thickness of the section is $5-10 \mathrm{~m}$. Bukivna suite is eroded.

After restoring sea conditions during Late Tithonian and Early Berriassian the stripe of the small bioherms (to 15-55 m thick) were formed on the depth of 25-30 m. Numerous well developed reefloving foraminifers and genetic relation with coral reef confirm it.

VII type of section (outlying) outcrops along the Dnister banks from Ustia Zelene to Nezvysko (the largest outcrop is near the Budzin and Gorygliady) and was opened by drilling in Lopushna, KorshivIspas, Krasnoilsk, Storozhunets and other areas. This section was formed in the periphery of Late Kimmeridgian - Early Tithonian back-reef basin and is represented by Nyzhniv suite. Conglomerates (6$10 \mathrm{~m}$ thick) composed of fragments of Paleozoic gray sandstones and dolomites and "old-red" sandstones with the Jurassic limestonic and dolomitic cement lie at the bottom. Over them there are oncoidal and micritic limestones (up to $12 \mathrm{~m}$ thick) overlapped by the succession of dolomites, dolomitic and bioclastic limestones, marls (up to $60 \mathrm{~m}$ thick). In the outcrops Nyzniv conglomerates lie on the eroded Paleozoic surface. Nyzhniv suite is overlapped by Albian-Cenomanian sands or Cenomanian sandstones. Thickness of this section is $65-70 \mathrm{~m}$.

Jurassic deposits decrease to the east. In the extreme east the littoral Upper Jurassic deposits were opened in the quarry near the village Korzhova (r. Zolota Lypa). In that section there is only Nyzhniv suite lied on the eroded surface of Devonian dolomites and represented by oolitic limestones interbedded by mudstones. Its thickness is $1,5-2 \mathrm{~m}$. At the bottom limestones substituted by sandstones with pebbles of Paleozoic rocks. Limestones contain the numerous favreins testifying about the sedimentation in extreme shallow and changeably salt water zone. Jurassic rocks are overlapped by Cenomanian conglomerates, which contain the pebbles and boulders of Upper Jurassic limestones formed of their wash-out at the beginning of Late Cretaceous. The Jurassic surface is generally eroded.

The main stages of forming carbonate complex. Correlation of the section types and the paleoecological conditions of their forming made it possible to determine that the main stages of the sedimentation of carbonate complex took place under the great influence of the eustatic changes. During Oxfordian a number of transgressive - regressive events occured against the long-term transgressive background. Forming biohermes by sponges at the bottom and by corals and algae above them and oncolitic limestones at the top was related with the regressive stage after Early Oxfordian and the great sea-level fall in Late Oxfordian. At Oxfordian - Kimmeridgian boundary sea-level falling to same level resulted in great erosion of biohermes, the sedimentation of mottled rocks at the bottom of Kimmeridgian formation and isolation of the evaporate lagoon on the periphery of basin. During Early Kimmeridgian normal sea conditions were restored because of the periodical regressive events against the global transgression. Late Kimmeridgian - Early Tithonian long-term transgression destroyed a lagoon and caused the sedimentation of limestones with the separate sponge bioherms. Deposits of this stage are the most widened in the region because of the transgression maximum at the middle of Thitonian. During Late Tithonian - Early Berriassian sea-level fluctuations against the global regression took place and barrier coral reef was formed. At the Early and Late Berriassian boundary maximum transgression stopped reef building in region and formed Upper Berriassian mudstone layers. Regressive stage was continued after that till the end of Valanginian. Big regressive events at the boundary of Berriassian and Valanginian, Early and Late Valanginian gave rise to the forming limestone formations. The next regressions and tectonic processes caused the erosion of carbonate complex.

\section{CONCLUSIONS}

The main stages of the sedimentation of Oxfordian Valanginian carbonate complex in the Ukrainian Precarpathians were related to eustatic sea-level chanding: Oxfordian (transgressive - regressive events against the long-term transgressive background), the Oxfordian - Kimmeridgian boundary (sea-level fall to same level), Early Kimmeridgian (periodical regressive events against the global transgression), Late Kimmeridgian - Early Tithonian (long-term transgression), Late Tithonian - Early Berriassian (great sea-level fluctuations against the global regression), the boundary of Early and Late Berriassian (transgressive maximum), Late Berriassian - Valanginian (regressive stage with 
big regressive events at the boundaries of Berriassian and Valanginian, Early and Late Valanginian). Stratigrafic correlation of the litofacial formations of the carbonate complex have been carried out.

The main factor of this carbonate complex forming was reef-building processes during Late Jurassic and Early Berriasian. Reef sediments (forereef, reef, back-reef, lagoon facies) are overlapped by the Upper Berriassian - Valanginian open shelf deposits. Seven types of the section formed in the different zones of paleobasin are fore-reef, reef, back-reef, transitional, lagoon, shallow-water, outlying. They are characterized by the specific lithological and paleontological composition. Fore-reef type of section formed in the deep zone of basin consists of the suites - Boniv (Oxfordian), Morantci (Kimmeridgian), Karolina (Tithonian - Lower Valanginian). Reef section is composed of Oxfordian biogerms (Rudki suite) and Kimmeridgian - Berriasian barrier reef (Opary suite). Back-reef section consist of the suites - back-reef Gorodok (Oxfordian), Pidluby or lagoon Rava-Russka (lower Kimmeridgian), Nyzhniv (Upper Kimmeridgian - Lower

\section{REFERENCES}

Anikeyeva O.V., 2002. Changing of the biocenoses of reefbuilding organisms during the Late Jurassic (Ukrainian Precarpathians). The evolution of organic world such as the base for deside of the problems of stratigraphy. Scientific works of the Institute of Geological sciences NAS of Ukraine. Kyiv, pp. 46-48. (In Ukrainian).

Anikeyeva O.V., 2005. Late Jurassic reefogenic complex of Ukrainian Precarpathians: biolithomicrofacies and stratigraphy. The candidat thesis on speciality 04.00.09 - palaeontology and stratigraphy. IGS NAS of Ukraine. Kyiv, 24 p. (In Ukrainian).

Zhabina N.M., Anikeyeva O.V., 2003. Evolution of belts of the Upper Jurassic carbonate shelf in Ukrainian Precarpathians. Papers of NAS of Ukraine, No 8, pp. 118-122. (In Ukrainian).

Zhabina N.M., Anikeyeva O.V., 2007. The new stratigraphic scheme of Upper Jurassic-Neocomian of Ukrainian Precarpathians. Digest of Science proc. UkrDGRI, No 3, pp. 46-56. (In Ukrainian).

Dulub V. G., Burova M. I., Burov V. S., Vishnjakov I. B., 1986. Explanatory report for the Stratigraphyc scheme of Jurassic deposits of Carpathian Foredeep and Volyno-Podolia outskirts of the East-European platform платформы. Leningrad, VSEGEI, 58 p. (In Russian).

Dulub V. G., Zhabina N.M., Ogorodnik M. E., Smirnov S.E., 2003. Explanatory report for the Stratigraphyc scheme of Jurassic deposits of Precarpathians (Stryi Jurassic basin). Lviv, LD UkrDGRI, 30 p. + scheme. (In Ukrainian).

Інститут геологічних наук НАН України, Київ, Україна

zhabinanatalia@gmail.com
Tithonian), Bukivna (Upper Tithonian - Lower Berriassian), Stavchany (Upper Berriassian - Valanginian). Transitional section is presented in the limits of the replacement of Oxfordian reef and back-reef facies (Rudki and Gorodok suites) and Lower Kimmeridgian back-reef and lagoon facies (Pidluby and Rava-Russka suites), overlapped by back-reef Nyzhniv and Bukivna suites with Stavchany suite at the top. Lagoon section determined on the territory of Kimmeridgian evaporite lagoon consists of RavaRusska, Nuzhniv, in places Bukivna and Stavchany suites. Shallow-water section formed in the shallow-water zone of back-reef basin represented by Nyzhniv and Bukivna suites. Outlying section formed in the periphery of Late Kimmeridgian Early Tithonian back-reef zone is represented by Nyzhniv suite. Model of the sedimentation these deposits is made on the base of the correlation of different types of section an in accordance with determined paleoecological conditions and stages of sedimentation.

Author wish to thank Dr. O.V. Samarska and Dr. O.V. Anikeyeva for discussions and advices.

Анікеєва О. В. Зміна біоценозів рифобудівних організмів на протязі пізньої юри (Передкарпатський прогин) / Анікеєва О. В. // Еволюція органічного світу як піАгрунтя Аля вирішення проблем стратиграфії. - Наук. праці ІГН НАНУ. - К., 2002. - C. 46-48.

Анікеєва О.В. Верхньоюрський рифогенний комплекс Українського Передкарпаття: біолітомікрофації та стратиграфія: автореф. Аис... канА. геол. наук: спец. 04.00.09 палеонтологія і стратиграфія. - К., 2005. - 24 с.

Жабіна Н. М. Еволюція поясів верхньоюрського карбонатного шельфу на території Українського Передкарпаття / Жабіна Н. М., Анікеєва О. В. // Аоповіді НАН України. 2003. - №8. - C.118-122.

Жабіна Н.М. Оновлена стратиграфічна схема верхньої юри-неокому Українського Передкарпаття / Жабіна Н.М., Анікеєва О.В. // Зб. наук. праць УкрАГРІ. - № 3. - 2007. - С. 46-56.

Объяснительнаязапискакрегиональнойстратиграфической схеме юрских отложений ПреАкарпатского прогиба и Волыно-Подольской окраины Восточно-Европейской платформы / [В. Г. Аулуб, М. И. Бурова, В. С. Буров, И. Б. Вишняков]. - А.: ВСЕГЕИ, 1986. - 58 с.

Пояснювальна записка до стратиграфічної схеми юрських відклаАів Передкарпаття (Стрийський юрський басейн) / [Аулуб В. Г., Жабіна Н. М., Огороднік М. Є., Смірнов С. Є.]. Аьвів: АВ УкрАГРІ, 2003. - 30 с.+ схема.

Рецензент: Н.В.Маслун 